\title{
Eğitim Fakültelerindeki Öğretim Elemanlarının Hayat Boyu Öğrenme Yeterlikleri İle Hayat Çapında Öğrenme Alışkanlıklarının İncelenmesi*
}

\author{
An Investigation on the Life-Long Learning Competencies \\ and Life-Wide Learning Habits of Lecturers in Faculties of \\ Education
}

\author{
Burak AYÇIÇEK** Tuğba YANPAR YELKEN***
}

\begin{abstract}
Öz: Bilgide meydana gelen hızlı değişimler ve buna bağlı olarak yaşanan toplumsal gelişmeler, bireylerin bilgiye ulaşmalarında ve yeni ögrenmelere duyulan gereksinmelerinde yenilikleri de beraberinde getirmektedir. $\mathrm{Bu}$ süreç ile içinde bulunduğumuz bilgi çağında bireylerin her yaşta, her yerde ve her konuda öğrenmelerini destekleyen hayat boyu öğrenme kavramının önemi vurgulanmaktadır. Hayat çapında öğrenme kavramı ise zamana ve fiziksel ortamlara sığdırılamayan sınırsız bir öğrenme anlayışııı ifade etmektedir. Yapılan bu araştırmanın amacı, eğitim fakültelerindeki öğretim elemanlarının hayat boyu öğrenme yeterlikleri ile hayat çapında öğrenme alışkanlıklarını incelemektir. Araştırmada betimsel yöntem kullanılmışır ve veriler 'Hayat Boyu Öğrenme Yeterlik Algısı Ölçeği' ve 'Hayat Çapında Öğrenme Alışkanlıkları Ölçeği' yoluyla elde edilmiştir. Araştırma, 2015-2016 akademik yılının birinci döneminde yedi farklı bölgede bulunan üniversitelerde görev yapan 276 öğretim elemaniyla gerçekleştirilmiştir. Elde edilen bulgulara göre, eğitim fakültelerindeki öğretim elemanlarının hayat boyu öğrenme yeterlikleri ile hayat çapında öğrenme alışkanlıkları yüksek düzeydedir. Hayat boyu öğrenme yeterlik algısı ölçeği alt boyutları ile hayat çapında öğrenme alışkanlıkları ölçeği alt boyutları arasında anlamlı düzeyde ilişkiler tespit edilmiştir.
\end{abstract}

Anahtar Kelimeler: Hayat boyu öğrenme, hayat çapında öğrenme, öğretim elemanı.

\begin{abstract}
Rapid changes that take place in information and in parallel with these changes, social developments lead to innovations for individuals about getting information and needs for their new learnings. In this process, the importance of life-long learning, which supports individuals' learning at any age, in any place and in any subject is emphasized in information age. The concept of life-wide learning reflects the idea of limitless learning which is independent from time and place. In this research, it is aimed to examine life-long learning competencies and life-wide learning habits of lecturers in faculties of education. In the research, descriptive method is used and the data has been obtained through 'Life-Long Learning Competency Scale' and 'Life-Wide Learning Habits Scale'. The research has been actualized with 276 academicians in education faculties of universities in seven different regions in the first period of 2015-2016 education year. The results obtained from the research show that the lecturers participated in the research have high level of life-long learning competencies and life-wide learning habits. Significant correlations are found between the lower sizes of 'life-long learning competency scale' and 'life-wide learning habits scale'

Keywords: Life-long learning, life-wide learning, lecturer.
\end{abstract}

\section{Giriş}

Günümüzde bilimsel, teknolojik ve kültürel alanlarda yaşanan gelişmeler, bilgideki değişmenin sürekliliği ve hızı bugünün insanını sürekli bir öğrenme ihtiyacı içinde bırakmıştır. Bu durumun sonucu olarak da günümüzde eğitim, insan hayatında belirli dönemlerle sınırlandırılamaz bir hale gelmiştir ve en gelişmiş ülkeler bile eğitimde niteliği arttırma arayışı içine girmişlerdir. Özellikle küreselleşme, Avrupa Birliği süreci ve Bologna süreci çalışmaları eğitim alanındaki

* İkinci Yazarın Danışmanlığında Yürütülen Yüksek Lisans Tezinden Üretilmiştir.

** Doktora Öğrencisi. Mersin Üniversitesi Eğitim Bilimleri Enstitüsü

*** Prof. Dr., Mersin Üniversitesi Eğitim Fakültesi Eğitim Bilimleri Enstitüsü, e-posta: tyanpar@gmail.com 
çalışmaların hız kazanmasına neden olmuştur. Çağımızın ihtiyaçları bireyin aktif olarak bilgi edinme sürecinde olmasını gerektirmektedir. Bu noktada, öğrenmeyi belli fiziksel ortamlara sığdırmak, öğrenme için bir son nokta belirlemek giderek zorlaşmaktadır. Bireyin, bilgiyi ezberleyen değil, bilgiye ulaşmasını bilen, bu bilgiyi kullanıp ürettiği bilgiyi paylaşabilen, öğrenmeyi öğrenmiş ve hayat boyu öğrenmeyi benimsemiş olması bilgi çağının gerektirdiği öğrenme hedeflerini oluşturmaktadır.

Bireyin içinde bulunduğu çağın gerektirdiği yeni ihtiyaçların giderilmesi için başta yükseköğretim kurumlarının olmak üzere bütün eğitim kurumlarının sorumlulukları vardır. Soylu'nun (2013) belirttiği gibi üst düzey insan gücünün kaynağı olarak görülen yükseköğretim kurumlarından günümüz şartlarıyla rekabet edebilmek için sürekli gelişim, hayat boyu öğrenme olanağı sağlama, kalite kültürünün yerleşmesi, yaratıcı ve tam donanımlı bireyler yetiştirme, firsat eşitliği bilinci, yeniliklere açık olma ve onları takip edebilme gibi bir dizi özelliği bünyelerinde bulundurmaları beklenmektedir. Sürekli değişen dünya düzeninde, bir toplumun varlığını sürdürebilmesi için yükseköğretim sisteminden beklentiler oldukça artmıştır. Baskan'a (2000) göre, firsat eşitliğini ve hayat boyu öğrenme olanağını sağlama, beceri kazandırmanın yanında bilgiye ulaşma, bilgiyi öğrenme ve kullanma yöntemlerini öğretme, etik değerleri öne çıkartarak toplumun geleceğini biçimlendirmede öncülük etme ve topluma karşı sorumluluğa dayalı bir özerkliğe sahip olma bu beklentiler arasındadır.

Mevcut bilgi, beceri ve yeteneklerin günümüz bilgi ve teknoloji çağının şartları doğrultusunda yenilenmesi gerektiğini vurgulayan hayat boyu ve hayat çapında öğrenme kavramları önemli bir gereksinim haline gelmiştir. $\mathrm{Bu}$ bağlamda bireylerin firsatları değerlendirebilmek için yeni bilgi ve becerilere sahip olması gerektiği ortaya çıkmaktadır. Yeni bilgi ve becerilere açık olan birey toplumsal ilerlemeye katkı sunabilir. Bilginin en büyük sermaye ve bilgili olmanın da en büyük güç olduğunu belirten Akkoyunlu'ya (2008) göre bilgi çağının temel özelliği, sürekli ve hızla artan değişimdir. Bilginin değişime paralel olarak hızlı bir şekilde arttığı çağımızda, mevcut bilgi aynı hızla güncelliğini kaybetmektedir.

'Hayat Boyu Öğrenme' olgusu bireylerin hayatları boyunca edindikleri bilgi, beceri ve tutumları içinde bulunduğumuz çağın şartlarına göre güncelleme fikrini vurgulamaktadır. Hayat boyu öğrenmenin gerekliliğini vurgulayan Demirel'e (2009) göre gelişmiş bir toplumda bireyler kitaplarla gerçek anlamda tanışmış, yenileşme ve gelişme için eksiklerini sorgulayan ve mükemmelleşme yolunda adımlar atabilen, özerklik kazanmış ve eleştirel düşünebilen kişilerdir. Hayat boyu öğrenme olgusu, öğrenmenin zorunluluktan ziyade bir yaşam biçimi olmas1 gerektiğini vurgulamaktadır. Hayat boyu öğrenmenin çocukluktan emekliliğe kadar sürekli öğrenmeyi ifade eden bir kavram olduğunu belirten Aktan'a (2007) göre hayat boyu öğrenme, formal öğrenmenin (ilk ve orta öğretim kurumlarında, üniversitelerde verilen eğitim) yanı sıra informal öğrenmeyi de (aile içi eğitim, topluluk içinde öğrenme vs.) içerir. Berberoğlu (2010), hayat boyu öğrenmenin, örgün eğitimin yetersiz olduğu, sanayinin ve toplumun ihtiyaçlarına cevap veremediği düşünüldüğü için önemli hale geldiğini belirterek, hayat boyu öğrenmenin, örgün eğitimin bir alternatifi değil, örgün eğitimde eksik ve yetersiz kalan verilerin sonradan tamamlanması olarak kabul edilmesi gerektiğini belirtmiştir.

Hayat boyu öğrenme kavramının yanında henüz üzerinde çok fazla konuşulmamış ve inceleme yapılmamış diğer bir olgu ise hayat çapında öğrenmedir. Bireylerin bilgi toplumlarında var olabilmeleri ve değişikliklere uyum sağlayarak kendilerini sürekli olarak yenileyebilmeleri için sahip olmaları gereken en temel becerilerden olan hayat çapında öğrenme olgusunun temelinde zamana ve fiziksel ortamlara sığdırılamayan sınırsız bir öğrenme anlayışı yatmaktadır. Günümüzde eğitimin belli yaş ve dönemlerde alınması gereken bir hizmet olduğu anlayışı yerini geleneksel öğrenme türlerine farklı bir boyutta yaklaşan hayat çapında öğrenme anlayışına bırakmaktadır. $\mathrm{Bu}$ öğrenme biçimi zorunlu olmaktan ziyade, bireyselleştirilmiş eğitim anlayışını temsil etmektedir: aynı durumdan farklı insanlar farklı şeyler öğrenirler. $\mathrm{Bu}$ öğrenme biçimi önceden belirlenmiş bir müfredattan bağımsız olarak kendiliğinden oluşmaktadır. Somut olaylarla daha anlamlı ve mantıklı hale gelmektedir. Bireylerin deneyimlerini ve ön öğrenmelerini de kapsayan öğrenme ortamını ifade eden kavram, gelecek öğrenmeler için çıkış noktası olabilir (Reischmann, 1986, 2; Akt. Jackson, 2011). Hayat çapında 
öğrenme sınıfta resmi ya da gayrı resmi öğrenmeler, staj hareketleri, ücretli veya ücretsiz yarı zamanlı işler, toplum hizmeti ve diğer gönüllülük hareketleri, seyahat veya diğer kültürlerle etkileşim esnasında maruz kalınan öğrenmeler, ebeveyn olmak gibi hayatın birçok alanını kapsamaktadır (Soylu, 2013). Bireylere kendilerini daha iyi tanıma firsatı veren hayat çapında öğrenme kavramı hem eğitim hayatıyla bağlantılı hem de meslek dışı fikirleri içine alan öğrenme tecrübelerini içermektedir. Jackson'a (2011) göre çoğu insan yaşları ya da bulundukları durum ne olursa olsun iş veya eğitim, ev yönetimi, aile üyesi olma, bir kulüp ya da toplulukta olma, tatile gitme, zihinsel, fiziksel ve ruhsal olarak kendilerine zaman ayırma gibi eş zamanlı olarak birçok farklı yerde bulunabilirler.

Hayat boyu öğrenme boyutunun karmaşık olduğu söylenemez, basit bir ifadeyle bireyin hayatı boyunca öğrendiklerini içerir. Bilgi ve yeteneklerin zaman aşımına uğraması, bireyin sürekli öğrenme süreci içerisinde mevcut yeterliklerini güncellemelerini gerekli kılmaktadır. Hayat çapında öğrenme kavramı ise daha kapsamlı içerik ve öğrenme ortamları içerdiğinden daha karmaşık bir kavramdır. Şekil 1'de hayat boyu ve hayat çapında öğrenmenin örgün ve yaygın eğitimle ilişkisi gösterilmektedir (Clark, 2005).

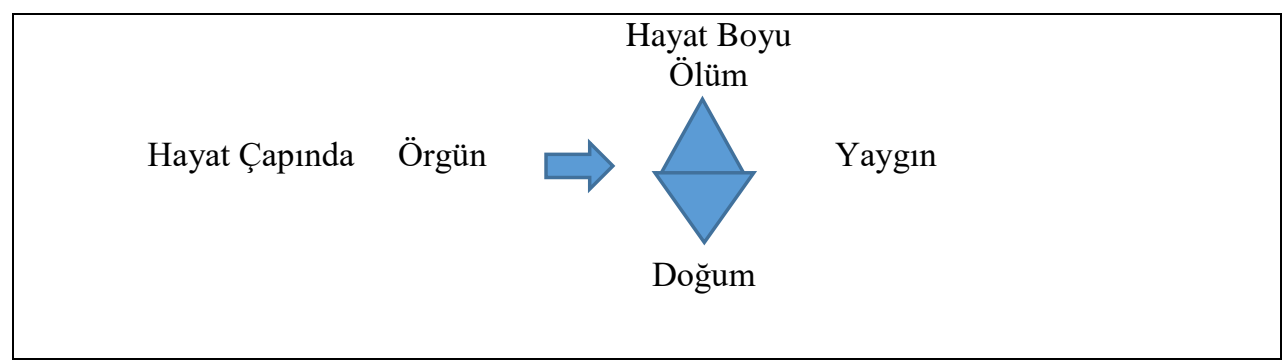

Şekil 1. Hayat Boyu ve Hayat Çapında Öğrenme Matrisi (Clark, 2005 s.52)

Bireyin kendini geliştirmesine yönelik her tür öğrenme ortamından yararlanarak bilgi, beceri, tutum ve alışkanlıklar kazanmasını öngören hayat boyu ve hayat çapında öğrenme kavramları üzerinde durulan bu çalışmada, hayat boyu öğrenme yeterliğinin ve hayat çapında öğrenme alışkanlıklarının ülkemiz üniversitelerinin eğitim fakültelerindeki var olan durumu ortaya konulmaya çalışılmıştır. Eğitim fakültesi öğretim elemanlarının hayat boyu öğrenme yeterlikleri ile hayat çapında öğrenme alışkanlıklarının belirlenmesinin faydalı olacă̆ 1 kabul edilebilir bir durumdur. Ayrıca hayat çapında öğrenmenin yeni bir konu olması bu kavramla ilgili yapılan çalışmaların çok fazla olmamasına neden olmuştur. Bu araştırma ile hayat boyu ve hayat çapında öğrenmelerin mevcut durumunu ortaya koymak ve bu kavramların eğitimde uygulanabilirliğine yönelik önerilerde bulunmak için bu araştırmanın ilgili literatüre katk1 sağlaması beklenilmektedir. $\mathrm{Bu}$ araştırmanın, bilgi toplumunun ve küreselleşmenin gerekli kıldığı nitelikli bireylerden oluşacak bir toplum yaratma, hayat boyu ve hayat çapında öğrenme kavramları hakkında öğretim elemanlarının bilinç düzeylerini araştırma ve bu kavramların ilkelerini tanıtma açısından önemli olduğu düşünülmektedir. $\mathrm{Bu}$ çalışmada eğitim fakültelerindeki öğretim elemanlarının hayat boyu öğrenme yeterlikleri ile hayat çapında öğrenme alışkanlıklarının araştırılması amaçlanmıştır. Bu amaç doğrultusunda şu sorulara cevap aranmıştır:

1. Eğitim fakültelerindeki öğretim elemanlarının hayat boyu öğrenme yeterlikleri nasıldır?

2. Eğitim fakültelerindeki öğretim elemanlarının hayat çapında öğrenme alışkanlıkları nasildır?

3. Eğitim fakültelerindeki öğretim elemanlarının hayat boyu öğrenme yeterlikleri ile hayat çapında öğrenme alışkanlıkları arasında bir ilişki var mıdır?

\section{Yöntem}

$\mathrm{Bu}$ çalışma, var olan durumu saptamak amacıyla tarama (survey) modeli kullanılarak yapılan betimsel bir çalışmadır. Tarama modeli, geçmişte veya halen var olan bir durumu var olduğu 
şekliyle betimlemeyi amaçlayan araştırma yaklaşımıdır (Karasar, 2000). Tarama modeli, geniş gruplar üzerinde yürütülen, bireylerin bir olay ya da olgu hakkındaki görüşlerinin, tutumlarının belirlendiği, olay ya da olgunun betimlenmesine dayalı olarak yapılan çalışmaları kapsamaktadır (Karakaya, 2011).

\section{Evren ve örneklem}

$\mathrm{Bu}$ araştırmanın çalışma grubunu, 2015-2016 akademik yılında her bölgeyi temsil edecek şekilde seçilen üniversitelerin eğitim fakültelerindeki 276 öğretim elemanı oluşturmaktadır. Örneklem belirlenirken amaçlı örneklem yöntemi kullanılmıştır. Katılımcıların 113'ü kadın, $(\% 40,9) ; 163$ 'ü erkektir $(\% 59,1)$. Öğretim elemanlarının 54'ü (\% 19,6) Doğu Anadolu Bölgesi'ndeki Üniversitede; 47'si (\%17) Marmara Bölgesi'ndeki Üniversitede; 41'i $(\% 14,9)$ Akdeniz Bölgesi'ndeki Üniversitede; 38'i (\%13,8) Karadeniz Bölgesi'ndeki Üniversitede; 37'si $(\% 13,4)$ Ege Bölgesi'ndeki Üniversitede; 34'ü $(\% 12,3)$ Güney Doğu Anadolu Bölgesi'ndeki Üniversitede ve 25'i $(\% 9,1)$ İç Anadolu Bölgesi'ndeki Üniversitede görev yapmaktadır. Öğretim elemanlarının 35'i $(\% 12,7)$ profesör; 37'si $(\% 13,4)$ doçent; 74'ü $(\% 26,8)$ yardımc1 doçent; 113 'ü $(\% 40,9)$ araştırma görevlisi; 10’u $(\% 3,6)$ öğretim görevlisi ve 7'si $(\% 2,5)$ okutmandır.

\section{Veri toplama araçları}

Hayat Boyu Öğrenme Yeterlik Algısı Ölçeği: Yelken ve Konokman (2014) tarafindan öğretim elemanlarının hayat boyu öğrenme yeterliklerine ilişkin algılarını belirlemek amacıyla geliştirilmiştir. Ölçeğin bütününe ilişkin Cronbach alfa güvenirlik katsayısı 928 olarak bulunmuştur. $\mathrm{Bu}$ araştırmada ise, ölçeğin bütününe ilişkin Cronbach alfa güvenirlik katsayısı ,.86 olarak bulunmuştur. Ölçme aracının başında örneklemi betimlemek amacıyla öğretim elemanlarına cinsiyet ve unvan bilgileri sorulmuştur. Katılımcıların hayat boyu öğrenme yeterliklerine ilişkin veri toplamaya yönelik oluşturulan ölçek hayat boyu öğrenme yeterliliğini içeren 39 madde olarak ve 5'li Likert tipinde "Tamamen Katıliyorum", "Katıliyorum", "Kararsızım", "Katılmıyorum", "Tamamen Katılmıyorum" hazırlanmıştır. Ölçekte bulunan, 1-3 maddeler Ana Dilde İletişim, 4-9 maddeler Yabancı Dilde İletişim, 10-15 maddeler Matematiksel Düşünme ve Problem Çözme, 16-20 maddeler Dijital Yeterlik ve 21-25 maddeler Öğrenmeyi Öğrenme Yeterliği, 26-32 maddeler Sanatsal Bilinç ve İfade Yeterliği, 27-30 maddeler Kültürel Bilinç, 33-39 maddeler Vatandaş Olma Bilinci ve Girişimcilik alt boyutlarını oluşturmuştur. Hayat Boyu Öğrenme Yeterlik Algısı Ölçeği'nin alt boyut güvenirlik katsayıları sirasıyla $.81 ; .84 ; .76 ; .71 ; .71 ; .70 ; .71 ; .70$ olarak bulunmuştur.

Hayat Çapında Öğrenme Alışkanlıkları Ölçeği: Soylu (2013) tarafindan eğitim fakültelerindeki öğretim elemanlarının hayat çapında öğrenme alışkanlıklarını belirlemek amacıyla geliştirilmiştir. Ölçeğin bütününe ilişkin Cronbach alfa güvenirlik katsayısı .85 olarak bulunmuştur. Ölçek, katılımcıların hayat boyu öğrenme yeterliklerine ilişkin veri toplamaya yönelik maddelerden oluşmaktadır. Ölçek, hayat çapında öğrenme alışkanlıklarını içeren 33 madde olarak ve 5'li Likert tipinde "Tamamen Katılıyorum", "Katılıyorum", "Kararsızım", "Katılmıyorum", "Tamamen Katılmıyorum" hazırlanmıştır. Ölçekte bulunan, 1-8 maddeler Mesleki Gelişim Alışkanlıkları, 9-13 maddeler Liderlik Alışkanlıkları, 14-19 maddeler Bakım Temelli Alışkanlıklar, 20-23 maddeler Kültürel Etkileşim Alışkanlıkları, 24-26 maddeler Boş Zaman Alışkanlıkları, 27-33 maddeler Problem Çözme Alışkanlıkları alt boyutlarını oluşturmuştur. 'Hayat Çapında Öğrenme Alışkanlıkları Ölçeği'nin alt boyut güvenirlik katsayıları sirasıyla.77; .74; .71;.72; .71;.70 olarak bulunmuş̧ur.

\section{Işlem}

Araştırmada kullanılan veri toplama araçları olan 'Hayat Boyu Öğrenme Yeterlik Algısı Ölçeği' ve 'Hayat Çapında Öğrenme Alışkanlıkları Ölçeği' kullanılarak elde edilen veriler, 2015-2016 eğitim öğretim yılının Ekim-Kasım aylarında yedi farklı üniversitenin eğitim fakültelerindeki öğretim elemanlarına posta yoluyla ulaşılarak elde edilmiştir. 


\section{Verilerin analizi}

Araştırmada 'hayat boyu öğrenme yeterlik algısı' ve 'hayat çapında öğrenme alışkanlıkları' ölçeklerinde elde edilen veriler SPSS programı kullanılarak analiz edilmiştir. Ölçekler ve alt boyutlardan elde edilen puanların normal dağılıp dağılmadığı test edilmiştir. Bunu test edebilmek için "Kolmogorov-Smirnov Tek Örneklem Testi (KS)" ve çarpıklık, basıklık katsayılarından yararlanılmıştır. KS testi sonucu incelendiğinde; "hayat boyu öğrenme yeterlik algısı" ve "hayat çapında öğrenme alışkanlıkları" ölçekleri alt boyutları ile ölçeklerin "genel toplam" puanlarının anlamlılık değerlerinin anlamlı olduğu $(\mathrm{p}<.05)$ görülmektedir. Bu sonuç ölçeklere ait puanların normal dağılım göstermediğini ortaya koymaktadır. Ayrıca basıklık ve çarpıklık değerlerinde de $+1,-1$ değerlerini aşan alt ölçek bulunmaktadır. Basıklık ve çarpıklık değerleri $+1,-1$ arasında ise verilerin normal dağıldığı kabul edilmektedir (Büyüköztürk, 2013). Araştırmada, iki grup karşılaştırmalarında (cinsiyet ve medeni durum değişkenleri) Mann Whitney U Testi ve ikiden fazla grup karşılaştırmalarında (bölüm, üniversite, unvan değişkenlerinde) Kruskal Wallis Testi, iki ölçek arasındaki ilişki (hayat boyu öğrenme yeterlik algısı ölçeği ve hayat çapında öğrenme alışkanlıkları ölçeği) hesaplamalarında da Spearman Brown Sıra Farkları Korelasyon Katsayısı kullanılmıştır

\section{Bulgular}

Öğretim elemanlarının hayat boyu ögrenme yeterliklerine ilişkin bulgular

"'Eğitim fakültelerindeki öğretim elemanlarının hayat boyu öğrenme yeterlikleri nasıldır?" sorusunun analizinde betimsel istatistikler kullanılmıştır. Sonuçlara ilişkin bulgular Tablo 1'de gösterilmiştir.

Tablo 1. Öğretim Elemanlarının “Hayat Boyu Öğrenme Yeterlik Algısı Ölçeği’nden Aldıkları Puanlara İlişkin Ortalama ve Standart Sapma Değerleri

\begin{tabular}{|c|c|c|c|c|c|c|c|c|c|c|}
\hline Madde & $\begin{array}{c}\text { H.B.Ö.Y. } \\
\text { Boyutları }\end{array}$ & $\mathrm{N}$ & $\bar{X}$ & $\mathrm{Ss}$ & Mod & Ranj & Min & Max & $\begin{array}{c}\text { Alınabilecek } \\
\text { En Yüksek } \\
\text { Puan }\end{array}$ & Yorum \\
\hline $1-39$ & Tüm Ölçek & 276 & 166,52 & 12,13 & 173 & 72 & 121 & 193 & 195 & Olumlu \\
\hline $1-2-3$ & $\begin{array}{c}\text { Ana Dilde } \\
\text { Iletişim }\end{array}$ & 276 & 13,37 & 1,58 & 15 & 9 & 6 & 15 & 15 & Olumlu \\
\hline $\begin{array}{c}4-5-6- \\
7-8-9\end{array}$ & $\begin{array}{c}\text { Yabanc1 } \\
\text { Dilde İletisisim }\end{array}$ & 276 & 22,81 & 4,75 & 24 & 24 & 6 & 30 & 30 & Olumlu \\
\hline $\begin{array}{c}10-11- \\
12-13- \\
14-15\end{array}$ & $\begin{array}{c}\text { Matematiksel } \\
\text { Düşüne ve } \\
\text { Problem } \\
\text { Çözme }\end{array}$ \\
\hline $\begin{array}{c}16-17- \\
18-19- \\
20\end{array}$ & $\begin{array}{c}\text { Dijital } \\
\text { Yeterlik }\end{array}$ & 276 & 26,67 & 2,63 & 30 & 12 & 18 & 30 & 30 & Olumlu \\
\hline $\begin{array}{c}21-22- \\
23-24- \\
25\end{array}$ & $\begin{array}{c}\text { Öğrenmeyi } \\
\text { Öğrenme } \\
\text { Yeterliği }\end{array}$ & 276 & 21,16 & 2,69 & 23 & 14 & 11 & 25 & 25 & Olumlu \\
\hline $\begin{array}{c}26-31- \\
32\end{array}$ & $\begin{array}{c}\text { Sanatsal } \\
\text { Bilinç ve } \\
\text { İfade } \\
\text { Yeterliği }\end{array}$ & 276 & 12,62 & 1,52 & 13 & 7 & 8 & 15 & 15 & Olumlu \\
\hline $\begin{array}{c}27-28- \\
29-30\end{array}$ & $\begin{array}{c}\text { Kültürel } \\
\text { Bilinç }\end{array}$ & 276 & 17,25 & 2,17 & 16 & 10 & 10 & 20 & 20 & Olumlu \\
\hline $\begin{array}{c}33-34- \\
35-36- \\
37-38- \\
39\end{array}$ & $\begin{array}{c}\text { Vatandaş } \\
\text { Olma Bilinci } \\
\text { ve } \\
\text { Girişimcilik }\end{array}$ & 276 & 30,29 & 2,67 & 31 & 14 & 21 & 35 & 35 & Olumlu \\
\hline
\end{tabular}


- Tablo 1 incelendiğinde, toplam puana ilişkin aritmetik ortalamanın 166,52; toplam puandan elde edilebilecek en düşük puanın 39, en yüksek puanın 195, ortalamanın 166,52 olduğu görülmektedir. Bu bulguya dayanarak öğretim elemanlarının "HBÖY Boyutlarına" ait toplam puanlarının yüksek olduğu ifade edilebilir.

- Hayat boyu öğrenme ölçeği alt boyutlarından "ana dilde iletişim" alt boyutunda katılımcıların görüşlerinin olumlu olduğu belirlenmiştir. Alınabilecek en yüksek puan 15 iken ortalama 13,37'dir Bu durum görüşlerin pozitif eğilimde olduğunu göstermektedir.

- Hayat boyu öğrenme ölçeği alt boyutlarından "yabancı dilde iletişim" alt boyutunda katılımcıların görüşlerinin olumlu olduğu belirlenmiştir. Alınabilecek en yüksek puan 30 iken ortalama 22,81'dir Bu durum görüşlerin pozitif eğilimde olduğunu göstermektedir.

- Hayat boyu öğrenme ölçeği alt boyutlarından "matematiksel düşünme ve problem çözme" alt boyutunda katılımcıların görüşlerinin olumlu olduğu belirlenmiştir. Alınabilecek en yüksek puan 30 iken ortalama 26,67'dir Bu durum görüşlerin pozitif eğilimde olduğunu göstermektedir.

- Hayat boyu öğrenme ölçeği alt boyutlarından "dijital yeterlik" alt boyutunda katılımcıların görüşlerinin olumlu olduğu belirlenmiştir. Alınabilecek en yüksek puan 25 iken ortalama 22,35'dir Bu durum görüşlerin pozitif eğilimde olduğunu göstermektedir.

- Hayat boyu öğrenme ölçeği alt boyutlarından "öğrenmeyi öğrenme yeterliği” alt boyutunda katılımcıların görüşlerinin olumlu olduğu belirlenmiştir. Alınabilecek en yüksek puan 25 iken ortalama 21,16'dır. Bu durum görüşlerin pozitif eğilimde olduğunu göstermektedir.

- Hayat boyu öğrenme ölçeği alt boyutlarından "sanatsal bilinç ve ifade yeterliği" alt boyutunda katılımcıların görüşlerinin olumlu olduğu belirlenmiştir. Alınabilecek en yüksek puan 15 iken ortalama 12,62 'dir $\mathrm{Bu}$ durum görüşlerin pozitif eğilimde olduğunu göstermektedir.

- Hayat boyu öğrenme ölçeği alt boyutlarından "kültürel bilinç" alt boyutunda katıllımcıların görüşlerinin olumlu olduğu belirlenmiştir. Alınabilecek en yüksek puan 20 iken ortalama 17,25'dir. Bu durum görüşlerin pozitif eğilimde olduğunu göstermektedir.

- Hayat boyu öğrenme ölçeği alt boyutlarından "vatandaş olma bilinci ve girişimcilik" alt boyutunda katılımcıların görüşlerinin olumlu olduğu belirlenmiştir. Alınabilecek en yüksek puan 35 iken ortalama 30,29'dur. Bu durum görüşlerin pozitif eğilimde olduğunu göstermektedir.

\section{Öğretim elemanlarının hayat çapında ögrrenme alışkanlıklarına ilişskin bulgular}

"Eğitim fakültelerindeki öğretim elemanlarının hayat çapında öğrenme alışkanlıkları nasıldır?" sorusunun analizinde betimsel istatistikler kullanılmıştır. Sonuçlar Tablo 2'de özetlenmiştir.

- Tablo 2 incelendiğinde, toplam puana ait aritmetik ortalamanın 139,09; toplam puandan elde edilebilecek en düşük puanın 33, en yüksek puanın ise 165 olduğu görülmektedir. $\mathrm{Bu}$ bulguya dayanarak akademisyenlerin "HÇÖA Boyutlarına" ait toplam puanlarının yüksek olduğu ifade edilebilir.

- Hayat çapında öğrenme ölçeği alt boyutlarından "problem çözme alışkanlıkları" alt boyutunda katılımcıların görüşlerinin olumlu olduğu belirlenmiştir. Alınabilecek en yüksek puan 35 iken ortalama 30,69'dur ve mod (30) ise ortalamaya yakındır. Bu durum görüşlerin pozitif eğilimde olduğunu göstermektedir.

- Hayat çapında öğrenme ölçeği alt boyutlarından "mesleki gelişim alışkanlıkları" alt boyutunda katılımcıların görüşlerinin olumlu olduğu belirlenmiştir. Alınabilecek en yüksek puan 40 iken ortalama 34,98'dir ve mod (35) ise ortalamadan yüksektir. Bu durum görüşlerin pozitif eğilimde olduğunu göstermektedir.

- Hayat çapında öğrenme ölçeği alt boyutlarından "kültürel etkileşim alışkanlıkları" alt boyutunda katılımcıların görüşlerinin olumlu olduğu belirlenmiştir. Alınabilecek en yüksek puan 20 iken ortalama 16,74'dür ve mod (18) ise ortalamadan yüksektir. Bu durum görüşlerin pozitif eğilimde olduğunu göstermektedir. 
- Hayat çapında öğrenme ölçeği alt boyutlarından "liderlik alışkanlıkları" alt boyutunda katılımcıların görüşlerinin olumlu olduğu belirlenmiş̧ir. Alınabilecek en yüksek puan 25 iken ortalama 19,96'dır ve mod (20) ise ortalamadan yüksektir. Bu durum görüşlerin pozitif eğilimde olduğunu göstermektedir.

- Hayat çapında öğrenme ölçeği alt boyutlarından "bakım temelli alışkanlıklar" alt boyutunda katılımcıların görüşlerinin olumlu olduğu belirlenmiştir. Alınabilecek en yüksek puan 30 iken ortalama 25,03 'dür ve mod (26) ise ortalamadan yüksektir. Bu durum görüşlerin pozitif eğilimde olduğunu göstermektedir.

- Hayat çapında öğrenme ölçeği alt boyutlarından "boş zaman alışkanlıkları" alt boyutunda katılımcıların görüşlerinin olumlu olduğu belirlenmiştir. Alınabilecek en yüksek puan 15 iken ortalama 11,69'dur ve mod (12) ise ortalamadan yüksektir. Bu durum görüşlerin pozitif eğilimde olduğunu göstermektedir.

Tablo 2. Öğretim Elemanlarının "Hayat Çapında Öğrenme Alışkanlıkları Ölçeği’nden Aldıkları Puanlara İlişkin Ortalama ve Standart Sapma Değerleri

\begin{tabular}{|l|c|c|c|c|c|c|c|c|c|c|}
\hline Madde & $\begin{array}{c}\text { H.Ç.Ö.A. } \\
\text { Boyutları }\end{array}$ & $\mathrm{N}$ & $\bar{X}$ & Ss & Mod & Ranj & Min & Max & $\begin{array}{c}\text { Alınabilecek } \\
\text { En Yüksek } \\
\text { Puan }\end{array}$ & Yorum \\
\hline $\begin{array}{l}12-28- \\
29-30- \\
31-32- \\
33\end{array}$ & $\begin{array}{c}\text { Problem } \\
\text { Çözme } \\
\text { Alışkanlıkları }\end{array}$ & 276 & 30,69 & 2,71 & 30 & 13 & 22 & 35 & 35 & Olumlu \\
\hline $\begin{array}{l}1-2-3- \\
7-8-9- \\
11-14\end{array}$ & $\begin{array}{c}\text { Mesleki } \\
\text { Gelişim } \\
\text { Alışkanlıkları }\end{array}$ & 276 & 34,98 & 3,41 & 35 & 20 & 20 & 40 & 40 & Olumlu \\
\hline $\begin{array}{l}21-22- \\
23-24\end{array}$ & $\begin{array}{c}\text { Kültürel } \\
\text { Etkileşim } \\
\text { Alışkanlıkları }\end{array}$ & 276 & 16,74 & 2,19 & 18 & 11 & 9 & 20 & 20 & Olumlu \\
\hline $\begin{array}{l}4-5- \\
10-13- \\
15\end{array}$ & $\begin{array}{c}\text { Liderlik } \\
\text { Alışkanlıkları }\end{array}$ & 276 & 19,96 & 2,99 & 20 & 13 & 12 & 25 & 25 & Olumlu \\
\hline $\begin{array}{l}6-16- \\
17-18- \\
19-20\end{array}$ & $\begin{array}{c}\text { Bakım Temelli } \\
\text { Alışkanlıklar }\end{array}$ & 276 & 25,03 & 2,77 & 26 & 15 & 15 & 30 & 30 & Olumlu \\
\hline $\begin{array}{l}25-26- \\
27\end{array}$ & $\begin{array}{c}\text { Boş Zaman } \\
\text { Alışkanlıkları }\end{array}$ & 276 & 11,69 & 2,22 & 12 & 10 & 5 & 15 & 15 & Olumlu \\
\hline $1-33$ & \begin{tabular}{c} 
Tüm Ölçek \\
\hline
\end{tabular} & 276 & 139,09 & 10,85 & 143 & 60 & 103 & 163 & 165 & Olumlu \\
\hline
\end{tabular}

Öğretim elemanlarının hayat boyu öğrenme yeterlikleri ile hayat çapında öğrenme alışkanlıkları arasındaki ilişkiye dair bulgular

$\mathrm{Bu}$ probleme yanıt aranırken "Pearson Momentler Çarpımı Korelasyon Katsayısı", hesaplanması düşünülmüştür. Ancak her iki ölçekten elde edilen puanların da dağılımı normal olmadığı için ilişki, "Spearman Brown Sıra Farkları Korelasyon Katsayısı"' ile hesaplanmıştır. Sonuçlar Tablo 3'te özetlenmiştir.

- Hayat çapında öğrenme alışkanlıkları ölçeğinin problem çözme alışkanlıkları alt boyutu ile yine hayat çapında öğrenme alışkanlıkları ölçeğinin boş zaman alışkanlıkları alt boyutu hariç tüm alt boyutları arasında pozitif yönde ve orta düzeyde anlamlı ilişki olduğu belirlenmiştir. Problem çözme alışkanlıkları alt boyutu ile hayat boyu öğrenme yeterlikleri ölçeğinin yabancı dilde iletişim, sanatsal bilinç ve ifade yeterliği ve kültürel bilinç alt boyutları hariç tüm alt boyutları arasında pozitif yönde ve orta düzeyde anlamlı ilişki olduğu belirlenmiştir. 
Eğitim Fakültelerindeki Öğretim Elemanlarının Hayat Boyu Öğrenme Yeterlikleri İle Hayat Çapında

Öğrenme Alışkanlıkları

Tablo 3. Hayat Boyu Öğrenme ve Hayat Çapında Öğrenme Ölçek ve Alt Ölçeklerinin İlişkisi

\begin{tabular}{|c|c|c|c|c|c|c|c|c|c|c|c|c|c|c|c|c|}
\hline Ölçekler & 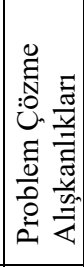 & 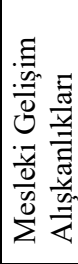 & 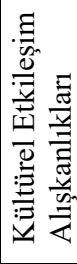 & 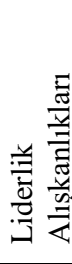 & 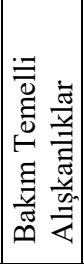 & 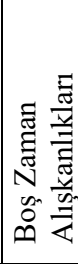 & 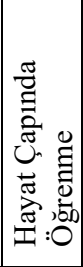 & 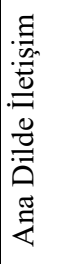 & 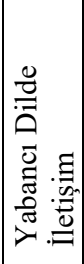 & 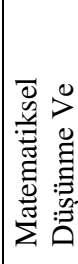 & 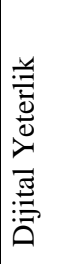 & 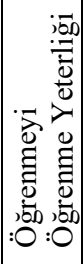 & 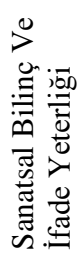 & 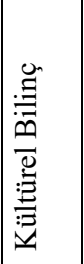 & 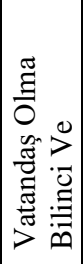 & 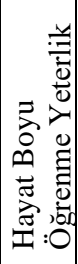 \\
\hline \multicolumn{17}{|l|}{$\begin{array}{l}\text { Problem Çözme } \\
\text { Alışkanlıkları }\end{array}$} \\
\hline \begin{tabular}{|l|} 
Mesleki Gelişim \\
Alışkanlıkları
\end{tabular} & $.56^{* *}$ & & & & & & & & & & & & & & & \\
\hline \begin{tabular}{|l|} 
Kültürel \\
Etkileşim \\
Alışkanlıkları \\
\end{tabular} & $.38 * *$ & $.38 * *$ & & & & & & & & & & & & & & \\
\hline \begin{tabular}{|l} 
Liderlik \\
Alışkanlıkları
\end{tabular} & $.37 * *$ & $.44 * *$ & $.26 * *$ & & & & & & & & & & & & & \\
\hline $\begin{array}{l}\text { Bakım Temelli } \\
\text { Alışkanlıklar }\end{array}$ & $.30 * *$ & $.42 * *$ & $.35 * *$ & $.46 * *$ & & & & & & & & & & & & \\
\hline $\begin{array}{l}\text { Boş Zaman } \\
\text { Alışkanlıkları }\end{array}$ & $.12 *$ & .03 & $.29 * *$ & $.20 * *$ & $.21 * *$ & & & & & & & & & & & \\
\hline $\begin{array}{l}\text { Hayat Çapında } \\
\text { Öğrenme } \\
\text { Alışkanlıkları }\end{array}$ & $.69^{* *}$ & $.75^{* *}$ & $.62 * *$ & $.70 * *$ & $.69^{* *}$ & $.39 * *$ & & & & & & & & & & \\
\hline \begin{tabular}{|l} 
Ana Dilde \\
İletişim
\end{tabular} & $.30 * *$ & $.37 * *$ & $.22 * *$ & $.35 * *$ & $.26 * * \mid$ & .11 & $.42 * *$ & & & & & & & & & \\
\hline $\begin{array}{l}\text { Yabancı Dilde } \\
\text { İletişim }\end{array}$ & $.18^{* *}$ & $.19 * *$ & $.30 * *$ & $.23 * *$ & $.15^{*}$ & $.26 * *$ & $.32 * *$ & $.21 * *$ & & & & & & & & \\
\hline $\begin{array}{l}\text { Matematiksel } \\
\text { Düşünme ve } \\
\text { Problem Çözme }\end{array}$ & $.42 * *$ & $.47 * *$ & $.14 *$ & $.20 * *$ & $.19 * *$ & .03 & $.39 * *$ & $.26 * *$ & $.18 * *$ & & & & & & & \\
\hline Dijital Yeterlik & $.30 * *$ & $.44 * *$ & $.20 * *$ & $.24 * *$ & $.24 * *$ & .00 & $.39 * *$ & $.29 * *$ & $.16^{* *}$ & $.54 * *$ & & & & & & \\
\hline $\begin{array}{l}\text { Öğrenmeyi } \\
\text { Öğrenme } \\
\text { Yeterliği }\end{array}$ & $.37 * *$ & $.42 * *$ & $.30 * *$ & $.39 * *$ & $.34 * *$ & .03 & $.48 * *$ & $.30 * *$ & .04 & $.36 * *$ & $.47 * *$ & & & & & \\
\hline $\begin{array}{l}\text { Sanatsal Bilinç ve } \\
\text { İfade Yeterliği }\end{array}$ & $.15^{* *}$ & .10 & $.21 * *$ & $.16^{* *}$ & $.21 * *$ & $.13 *$ & $.22 * *$ & $.22 * *$ & .00 & $.22 * *$ & $.20 * *$ & $.21 * *$ & & & & \\
\hline Kültürel Bilinç & $.28 * *$ & $.29 * *$ & $.25 * *$ & $.23 * *$ & $.31 * *$ & .04 & $.39 * *$ & $.31 * *$ & .01 & $.30 * *$ & $.29 * *$ & $.36^{* *}$ & $.31 * *$ & & & \\
\hline $\begin{array}{l}\text { Vatandaş Olma } \\
\text { Bilinci ve } \\
\text { Girişimcilik }\end{array}$ & $.38 * *$ & $.42 * *$ & $.19 * *$ & $.35 * *$ & $.34 * *$ & .04 & $.48 * *$ & $.30 *$ & .06 & $.49 * *$ & $.46 * *$ & $.43^{* *}$ & $.27 * *$ & $.38^{* *}$ & & \\
\hline $\begin{array}{l}\text { Hayat Boyu } \\
\text { Öğrenme Yeterlik } \\
\text { Algisı }\end{array}$ & $.50 * *$ & $.57 * *$ & $.38 * *$ & $.43 * *$ & $.39 * *$ & $.15^{* *}$ & $.64 * *$ & $.54 * *$ & $.49 * *$ & $.69 * *$ & $.68 * *$ & $.63^{* *}$ & $.39 * *$ & $.53^{* *}$ & $.67 * *$ & \\
\hline
\end{tabular}

- Hayat çapında öğrenme alışkanlıkları ölçeğinin mesleki gelişim alışkanlıkları alt boyutu ile yine hayat çapında öğrenme alışkanlıkları ölçeğinin boş zaman alışkanlıkları alt boyutu hariç tüm alt boyutları arasında pozitif yönde ve orta düzeyde anlamlı ilişki olduğu belirlenmiştir. Mesleki gelişim alışkanlıkları alt boyutu ile hayat boyu öğrenme alışkanlıkları ölçeğinin yabancı dilde iletişim ve sanatsal bilinç ve ifade yeterliği alt boyutları hariç tüm alt boyutları arasında pozitif yönde ve orta düzeyde anlamlı ilişki olduğu belirlenmiştir.

- Hayat çapında öğrenme alışkanlıkları ölçeğinin mesleki gelişim alışkanlıkları alt boyutu ile yine hayat çapında öğrenme alışkanlıkları ölçeğinin boş zaman alışkanlıkları alt boyutu hariç tüm alt boyutları arasında pozitif yönde ve orta düzeyde anlamlı ilişki 
olduğu belirlenmiştir. Mesleki gelişim alışkanlıkları alt boyutu ile hayat boyu öğrenme alışkanlıkları ölçeğinin yabancı dilde iletişim ve sanatsal bilinç ve ifade yeterliği alt boyutları hariç tüm alt boyutları arasında pozitif yönde ve orta düzeyde anlamlı ilişki olduğu belirlenmiştir.

- Hayat çapında öğrenme alışkanlıkları ölçeğinin kültürel etkileşim alışkanlıkları alt boyutu ile yine hayat çapında öğrenme alışkanlıkları ölçeğinin boş zaman alışkanlıkları alt boyutu hariç tüm alt boyutları arasında pozitif yönde ve orta düzeyde anlamlı ilişki olduğu belirlenmiştir. Kültürel etkileşim alışkanlıkları alt boyutu ile hayat boyu öğrenme yeterlik algısı ölçeğinin, yabancı dilde iletişim ve öğrenmeyi öğrenme yeterliği alt boyutları arasında pozitif yönde ve orta düzeyde anlamlı ilişki olduğu belirlenmiştir.

- Hayat çapında öğrenme alışkanlıkları ölçeğinin liderlik alışkanlıkları alt boyutu ile yine hayat çapında öğrenme alışkanlıkları ölçeğinin boş zaman alışkanlıkları alt boyutu hariç tüm alt boyutları arasında pozitif yönde ve orta düzeyde anlamlı ilişki olduğu belirlenmiştir. Liderlik alışkanlıkları alt boyutu ile hayat boyu ögrenme yeterlik algısı ölçeğinin ana dilde iletişim, öğrenmeyi öğrenme yeterliği ve vatandaş olma bilinci ve girişimcilik alt boyutları arasında pozitif yönde ve orta düzeyde anlamlı ilişki olduğu belirlenmiștir.

- Hayat çapında öğrenme alışkanlıkları ölçeğinin bakım temelli alışkanlıklar alt boyutu ile yine hayat çapında öğrenme alışkanlıkları ölçeğinin boş zaman alışkanlıkları alt boyutu hariç tüm alt boyutları arasında pozitif yönde ve orta düzeyde anlamlı ilişki olduğu belirlenmiştir. Bakım temelli alışkanlıklar alt boyutu ile hayat boyu öğrenme yeterlik algısı ölçeğinin öğrenmeyi öğrenme yeterliği, kültürel bilinç, vatandaş olma bilinci ve girişimcilik alt boyutları arasında pozitif yönde ve orta düzeyde anlamlı ilişki olduğu belirlenmiştir.

\section{Tartışma / Sonuç ve Öneriler}

Araştırmada ilk olarak eğitim fakültelerindeki öğretim elemanlarının hayat boyu öğrenme yeterlikleri sorgulanmıştır. Hayat boyu öğrenme ölçeği toplam puanları, öğretim elemanlarının hayat boyu öğrenme yeterliğine ilişkin algılarının yüksek olduğunu göstermektedir. Öğretim elemanlarının ana dilde iletişim, yabancı dilde iletişim, matematiksel düşünme, problem çözme, dijital yeterlik, öğrenmeyi öğrenme, kültürel bilinç, vatandaş olma bilinci ve girişimcilik yeterliklerinin yüksek olduğu söylenebilir. Ayrıca öğretim elamanlarının hayat boyu öğrenme yeterlik algılarının olumlu yönde olması, hayat boyu öğrenmeyi yaşamlarının önemli bir parçası olarak gördükleri şeklinde yorumlanabilir. Öğretim elemanlarının akademik çalışmaları dışında da öğrenmeyi bir hayat felsefesi olarak kabul ettikleri, ana dil kullanımına önem verdikleri, karşılaştıkları problemleri farklı çözüm yollarına başvurarak çözme eğiliminde oldukları, yabancı dil/dilleri akademik çalışmalarında ve günlük hayatlarında kullandıkları, çeşitli topluluklara ve sanatsal faaliyetlere katılıp sanatsal ürünlere karşı ilgi duydukları, teknolojiyi amaçları dahilinde kullanabildikleri, öğrenme için kendilerine zaman ayırdıkları, kültürel farklılıklara karşı olumlu bir tutum içinde oldukları, kişisel ve mesleki alanlarda yeniliklere açık oldukları ve sosyal sorumluluk almaktan çekinmedikleri sonuçlarına ulaşılabilir. Hayat boyu öğrenmenin önemini ortaya koyan bir çalışma Demir (2011) tarafından yapılmıştır. 'Hayat boyu Öğrenme Programının, İnsan Kaynaklarının Mesleki Sosyal Gelişimine, İstihdamına ve Yeterliklerin Tanınmasına Sağladığı Katkı Açısından Değerlendirilmesi' başlıklı çalışmada, hayat boyu öğrenmenin bireylerin mesleki, sosyal ve yabancı dil gelişimine katkısı ile yeterliklerin tanınmasına ve kurumların çevresiyle olan işbirliklerine katkı düzeyleri, bulgulara dayalı olarak ortaya konulmaya çalışılmıştır. Araştırmanın sonucunda hayat boyu öğrenme programlarının, mesleki ve teknik ortaöğretim kurumlarında görevli yönetici ve ögretmenlerin mesleki gelişimine, yabancı dil gelişimine ve kurumların çevresiyle olan işbirliklerine katkısı iyi düzeyde bulunmuştur.

Araştırmada, öğretim elemanlarının hayat çapında öğrenme alışkanlıklarına ilişkin algılarının yüksek olduğu bulunmuştur. Öğretim elemanlarının problem çözme, mesleki gelişim, 
kültürel etkileşim, liderlik, bakım temelli ve boş zaman alışkanlıklarına yönelik olumlu bir tutum sergiledikleri söylenebilir. Özellikle mesleki gelişim alt boyutu madde puanlarının yüksek olması öğretim elemanlarının alanlarındaki yenilikleri takip ettikleri ve kendilerini sürekli geliştirmeye çalıştıkları şeklinde yorumlanırken; bakım temelli alışkanlıklar alt boyutu madde puanlarının yüksek olması öğretim elemanlarının sadece mesleki olarak değil kişisel olarak da gelişimlerini sürdüklerini göstermektedir. Hayat çapında öğrenme alışkanlıklarından mesleki gelişim gereksinimlerine yönelik tasarlanacak mobil öğrenme sisteminde temel amaç sadece teknolojilerin kullanımı değil, akademisyenlerin bu sistemi kullanarak mesleki gelişim gereksinimlerini karşılamasıdır. Geliştirilmesi hedeflenen sistemin yetişkinlere yönelik olmasından dolayı yetişkinlerin gereksinimlerine cevap vermesi ve onlara fayda sağlaması, onların mobil öğrenme sistemini kullanmalarını olumlu etkilediğini göstermektedir (Knowles, 1998; Sampson, 2006; Akt. Keskin, 2011). Bu tespit ile mesleki gelişim ile teknoloji arasındaki ilişki ortaya çıkmaktadır. Özellikle hayat boyu öğrenme yeterliklerinden biri olan dijital yeterlik algısı ile hayat çapında öğrenme alışkanlıklarından mesleki gelişim arasındaki pozitif ilişki vurgulanmaya değerdir.

Elde edilen sonuçlara göre hayat boyu ve hayat çapında öğrenme özelliğine sahip öğretim elemanlarının kendilerini geliştirmeleri bağlamında hangi niteliklere sahip olmaları gerektiğinin farkında oldukları görülmüştür. Ayrıca, öğretim elemanlarının mevcut bilgi, beceri ve yeterliklerini geliştirmek için her türlü yeniliğe açık oldukları şeklinde yorum yapılabilir. Gediklioğlu'na (2005) göre, bir toplumda yükseköğretim görmüş bireylerin sayısı arttıkça, hayat boyu öğrenme kavramı toplum hayatına girmiş ve toplumsal değişim de o ölçüde hız kazanmış olmaktadır. Hayat çapında öğrenme alışkanlıkları ölçeğinin boş zaman alışkanlıkları alt boyutunun hayat çapında öğrenme alışkanlıklarının alt boyutlarından mesleki gelişim alışkanlıkları alt boyutu dışındaki boyutlarla pozitif ve anlamlı düzeyde ilişkili olduğu belirlenmiştir. $\mathrm{Bu}$ sonuç, öğretim elemanlarının boş zamanlarını etkili kullanmasıyla hayat çapında öğrenme alışkanlıklarının arttığını ancak mesleki gelişimlerinin bu durumdan olumsuz etkilendiğini göstermektedir. Boş zaman yaratmanın önemi üzerinde duran Çolakoğlu (2005) tarafından yapılan 'Üniversite Öğretim Elemanlarının Boş Zaman Alışkanlıklarını Değerlendirmeleri Üzerine Bir Araştırma' adlı çalışmada, öğretim elemanlarının çalışma saatlerinin fazla olduğu, boş zaman aktivitelerine fazla zaman ayıramadıkları, ortam ve şartlar oluştuğu takdirde çeşitli faaliyetlere katılabilecekleri yönünde görüş belirtmişlerdir.

Hayat boyu öğrenme bir yaşam felsefesi haline gelmesi gereken bir özelliktir. Hayat boyu öğrenme yeterliğine sahip olmak için sadece üniversitede görev yapmak yeterli değildir. Hayat boyu öğrenme felsefesini içselleştirerek "öğrenmeyi öğrenme", "sanatsal bilinç ve ifade yeterliği", " kültürel bilinç" gibi yeterlikleri kazandıracak yaşantılar oluşturulabilir. Yurt dışı üniversiteler ile ortak projeler geliştirilerek, öğretim elemanlarının farklı ortamlardaki eğitimöğretim faaliyetlerine katılmaları kolaylaştırılabilir. E-öğrenme uygulamaları hayat boyu eğitim olanağını başarılı bir şekilde desteklemektedir. Zaman ve mekân kısıtlamalarının kaldırılabilmesi eğitime yeni bir boyut kazandırmaktadır. $\mathrm{Bu}$ bağlamda e-öğrenme uygulamalarının en yüksek kalitede yürütülebilmesi için çalışmalar gerçekleştirilebilir. Ayrıca, ülkemiz için yeni bir kavram olan hayat çapında öğrenmenin önemini kavratacak tanıtım çalışmaları yapılabilir. Üniversitelerde, hayat çapında öğrenme alışkanlıklarını olumlu yönde etkileyecek ve farkındalık kazandıracak etkinlikler düzenlenebilir. Uluslararası projeler aracılığıyla hayat çapında öğrenme faaliyetlerine yön verecek çalışmalar yapılabilir. İleride yapılacak çalışmalar kapsamında üniversite dışında farklı okul düzeylerinde hayat boyu öğrenme yeterlikleri ve hayat çapında öğrenme alışkanlıkları araştırılabilir.

\section{Kaynaklar}

Akkoyunlu, B.(2008). Bilgi okuryazarlığı ve yaşam boyu öğrenme. 02.09.2015 tarihinde ietc2008.home.anadolu.edu.tr/ietc2008/1b.doc adresinden erişilmiştir.

Aktan, C. (2007). Yükseköğretimde değişim: Global trendler ve yeni paradigmalar. Yaşar Üniversitesi Yayını. İzmir. 
Baskan, G. (2000). Yirmi birinci yüzyılda yükseköğretim vizyon ve eylem. Kuram ve Uygulamada Ë̆itim Yönetimi. 6(22),167-189.

Berberoğlu, B. (2010). Yaşam boyu öğrenme ile bilgi ve iletişim teknolojileri açısından Türkiye'nin Avrupa Birliği’ndeki konumu. Bilgi Ekonomisi ve Yönetimi Dergisi, 5(2), 113-117.

Büyüköztürk, Ş. (2013). Sosyal bilimler için veri analizi el kitabı. Ankara: Pegem Yayıncılık.

Clark, T. (2005). Lifelong, life-wide or life sentence? Australian Journal of Adult Education, 45 (1), 47-62.

Çolakoğlu, T. (2005). Üniversite öğretim elemanlarının boş zaman alışkanlıklarını değerlendirmeleri üzerine bir araştırma. Gazi Eğitim Fakültesi Dergisi, 25(1), 247258.

Demir, İ. (2011). Hayat boyu ögrenme programının insan kaynaklarının mesleki sosyal gelişimine, yabancı dil gelişimine, istihdamina ve yeterliliklerin tanınmasına sağladiğ katkl açısından değerlendirilmesi. Yayımlanmamış doktora tezi. Ankara: Gazi Üniversitesi, Eğitim Bilimleri Enstitüsü.

Demirel, M. (2009). Yaşam boyu öğrenme ve teknoloji. 9. Uluslararası Eğitim Teknolojisi Konferans1, Ankara, Türkiye.

Gediklioğlu, T. (2005). Avrupa Birliği sürecinde eğitim sistemi: Sorunlar ve çözüm önerileri. Mersin Üniversitesi Eğitim Fakültesi Dergisi, 1(1), 66-80.

Jackson, N. (Ed.) (2011). The lifelong and lifewide dimensions of living and learning. In $\mathrm{N}$. Jackson (Eds.), Learning for a Complex World (p.22-38). USA: Author House.

Karakaya, İ. (2011). Bilimsel araştırma yöntemleri. Ankara: Anı Yayıncıl1k,

Karasar, N. (2000). Bilimsel araştırma yöntemi-kavramlar, ilkeler, teknikler. 10.Bask1. Ankara: Nobel Yayınevi.

Keskin, N. (2011). Akademisyenler için bir mobil öğrenme sisteminin geliştirilmesi ve sınanması. Yayımlanmamış doktora tezi. Eskişehir: Anadolu Üniversitesi, Eğitim Bilimleri Enstitüsü.

Soylu, B. (2013). Eğitim fakültelerindeki öğretim elemanı ve öğrencilerin hayat çapında ögrenme (life-wide learning) alışkanlıklarl ve üniversite yaşamına giriş dersi üzerine bir inceleme. Yayınlanmamış doktora tezi. Mersin: Mersin Üniversitesi Eğitim Bilimleri Enstitüsü.

Yelken, T. ve Konokman, G. (2014). Eğitim fakültesi öğretim elemanlarının yaşam boyu öğrenme yeterliklerine ilişkin algıları. Hacettepe Üniversitesi Eğitim Fakültesi Dergisi, 29(2), 267-281.

\section{Extended Abstract}

\section{Introduction}

Rapid changes that take place in information and in parallel with these changes, social developments lead to innovations for individuals about getting information and needs for their new learnings. In this process, the importance of life-long learning, which supports individuals' learning at any age, in any place and in any subject is emphasized in information age. The concept of life-wide learning reflects the idea of limitless learning which is independent from time and place.

All education institutions especially higher education institutions have responsibilities to meet the needs required by 21 st century. Life-long learning and life-wide learning which emphasize the importance of updating information, abilities and skills according to the age of information and technology, have become important necessities. In this context, individuals are supposed to get new knowledge and abilities to make use of oppurtunities. Individuals who are open to develop themselves can contribute to development of societies. According to Akkoyunlu (2008), the main characteristic of information age is constant and rapid change. Available information lose its currency in paralel with changes in the age in which information increase so much. 
Life-long learning emphasizes the idea of updating information, abilities and skills according to the requirements of the age. Clark (2005) describes the concept life-long learning as learning activities in life. According to Aktan (2007), a lifelong learning framework encompasses learning throughout the life cycle, from early childhood to retirement and includes formal learning and informal learning.

Another concept about which there is not enough argument or research is life-wide learning. Life-wide learning which points out limitless learning understanding, independent from time and place, is one of the necessary abilities for individuals to exist in information society and to develop themselves by adapting to changes.

In the past, education was regarded as a compulsory service, given in certain age and periods, but now there is a modern education understanding: life-wide learning. According to Jackson (2011), life wide learning is not complicated concept; 'lifewideness' adds value to 'lifelongness' by recognising that most people, no matter what their age or circumstances, simultaneously inhabit a number of different spaces - like work or education, running a home, being a member of a family and or caring for others, being involved in a club or society, travelling and taking holidays and looking after their own wellbeing mentally, physically and spiritually.

This study is regarded as important, in terms of investigating consciousness level of lecturers about the concepts, life-long learning and life-wide learning, introducing the principles of these concepts and creating a society consisting of qualified individuals required by information society and globalization. The purpose of this study is to investigate life-long learning competencies and life-wide learning habits of lecturers in faculties of education.

\section{Method}

In the research, descriptive method is used and the data has been obtained through 'Life-Long Learning Competency Scale' developed by Yelken ve Konokman (2014) to determine perceptions of lectures about life-long learning competencies according to gender, marital status, academic title and department variables and 'Life-Wide Learning Habits Scale' developed by Soylu (2013) to determine life-wide learning habits of lecturers in education faculties according to gender, academic title and department variables. The research has been actualized with 276 academicians in education faculties of universities in seven different regions in the first period of 2015-2016 education year. 35 professor $(\% 12,7), 37$ associate professor $(\% 13,4), 74$ assistant professor; 113 research assistant $(40,9), 10$ university lecturers $(\% 3,6)$ and 7 instructors $(\% 2,5)$ are included in the study. \%40,9 of participants (113) are women and $\% 59,1$ of participants (163) are men. The differences between scale scores have been examined in tems of various variables (gender, university, marital status, title, department). Mann Whitney U and Kruskal Wallis Tests have been used to compare averages and variances obtained from scales and lower sizes. Spearman Brown rank correlation coefficient has been used to examine the relation between two scales.

\section{Results and Discussion}

In the study, life-long learning competencies of lecturers have been investigated. Total scores of life-long learning scale show that perceptions of lecturers about life-long learning are high. Lecturers have positive attidudes towards communication in mother tongue, communication in foreign language, mathematical thinking, solving problem, digital competence, learning to learn, cultural consciousness, citizenship consciousness and entrepreneurship competences. Demir (2011) reveals the importance of life-long learning in his study, 'Evaluation of Life - Long Learning Program in Terms of Its Contribution to Professional and Social Development, Employment and Recognition of Competences of Human Resource'. In his study, contribution of life-long learning to individuals in terms of professional, social and improvement of foreign language and to institutions in terms of their collaboration with other institutions have been revealed based on findings. At the end of the study, it is found that life-long learning is useful 
and necessary for teachers in their fields and institutions in their collaborations with environment.

In the study, perceptions of lecturers about life-wide learning habits have been found high. Lecturers have positive attitudes towards problem solving, career development, cultural interaction, leadership, personal care and free time habits. Especially, the fact that scores of subdimension 'career developmet' are high show that lecturers follow the lastest developments in their fields and develop themselves. Also, scores of 'personal care' sub-dimension are so high that it can be said that lecturers develop themselves not only vocationally, but also personally.

Another result of the study shows that lectures who have life-long learning competencies and life-wide learning habits are conscious of which qualifications they need to develop themselves. Also, it can be commented that lecturers are open to changes to develop their knowledge, abilities and skills. According to Gediklioğlu (2005), if the number of individuals who get higher education increase in a society, life-long learning can be interiorised easily and social change is possible in that society.

Common projects with foreign universities should be developed, by this way lecturers get the chance of participating in different education activities in frame of life-long learning. $\mathrm{E}$ learning should be applied by creating education environments, independent from time and place. Also, a new concept, life-wide learning should be introduced in universities to create awareness. 